\title{
A influência da religião na esfera política: protestantismo e liberdade religiosa
}

\author{
Eumar Evangelista de Menezes Júnior* \\ Rildo Mourão Ferreira* \\ Marcos Vinicius Borges Alvarenga ${ }^{* * *}$
}

\section{Resumo}

O presente artigo busca ser uma exposição panorâmica, ressaltando a implicação dos temas da religião e da política na história cristã, desde os seus inícios, conforme descrito no Evangelho, passando pelo cristianismo antigo e medieval, com destaque para o período escolástico e renascentista e, finalmente, se detendo no fenômeno religioso do protestantismo e sua estreita ligação com o advento da modernidade, recuperando suas bases filosóficas e culturais, com o recorte em sua significação social para os novos tempos.

Palavras-chave: Modernidade. Protestantismo. Política. Liberdade.

\section{The influence of religion in the political sphere: protestantism and religious freedom}

\section{Abstract}

The present article seeks to be a panoramic exposition, emphasizing the implication of the themes of religion and politics in Christian history, from its beginnings, as

* Doutorando. Mestre. Especialista. Membro da União Literária Anapolina - ULA. Professor do Centro Universitário de Anápolis - UniEVANGÉLICA.

E-mail: profms.eumarjunior@gmail.com

** Pós Doutor. Doutor. Mestre. Especialista. Membro da União Literária Anapolina - ULA. Professor do Centro Universitário de Anápolis - UniEVANGÉLICA. Professor da Universidade de Rio Verde - UniRV. E-mail: rildomourao@uol.com.br

*** Pesquisador do Núcleo de Pesquisa em Direito - NPDU - Sociedade e Direitos Humanos - do Centro Universitário de Anápolis - UniEVANGÉLICA. Advogado.

E-mail: marcosviniciusalvarenga@gmail.com 
described in the Gospel, passing through ancient and medieval Christianity, especially the scholastic and Renaissance period and, finally, dwelling on the religious phenomenon of Protestantism and its close connection with the advent of modernity, recovering its philosophical and cultural foundations, with its social significance for the new times.

Key-words: Modernity. Protestantism. Politics. Freedom.

\section{La influencia de la religión en la esfera política: protestantismo y libertad religiosa}

\section{Resumen}

El presente artículo busca ser una exposición panorámica, resaltando la implicación de los temas de la religión y de la política en la historia cristiana, desde sus inicios, según lo descrito en el Evangelio, pasando por el cristianismo antiguo y medieval, con destaque para el período escolástico y renacentista y finalmente se detenía en el fenómeno religioso del protestantismo y su estrecha relación con el advenimiento de la modernidad, recuperando sus bases filosóficas y culturales, con el recorte en su significación social para los nuevos tiempos.

Palabras clave: Modernidad, protestantismo, política, libertad.

\section{Introdução}

A cultura ocidental favoreceu a coexistência entre religião e política. Mesmo nos momentos de diatribes irreconciliáveis, a sombra de uma acompanhava a outra. Se a religião era o "fato social" par excellence, como pensava Durkheim, a política, desde tempos imemoriais, foi a forma encontrada para a vida em sociedade - elas ocupavam o mesmo espaço - os sacerdotes e soberanos com frequência eram vistos juntos, ainda que tivessem diferenças e concorressem entre si.

A civilização grega fazia coabitar a Ágora com o Panteão de deuses, mais que isso, se a Ágora serviu também para a veiculação de doutrinas religiosas, hoje os muitos panteões existentes são mausoléus de benfeitores da nação não necessariamente religiosos. O helenismo nos legou a possibilidade de interação e justaposição dos dois campos. E se em muitos capítulos dessa rica história cultural houve necessidade de separação entre os dois poderes, é porque na verdade andavam juntos. A experiência da cultura judaicocristã não foge a essa regra, os dois campos se alternam, se sobrepõem, e sincreticamente se ajustam.

Antes, porém, de aprofundarmos essa questão no caso protestante, faz-se necessário um repasse histórico acerca dos temas religião e política, vinculados ao fenômeno histórico do cristianismo antigo. 


\section{Religião e política na história cristã}

$O$ momento $\alpha$ (alfa) - O caminho que se inicia com as máximas do Evangelho: "Dai pois a César o que é de César, e a Deus o que é de Deus" (Mt 22,21) e "O meu reino não é deste mundo" (Jo 18,36), constituem, por assim dizer, o cerne da utopia cristã acerca da Basiléia tón Teón e, em seguida, o desenrolar dos fatos históricos ulteriores que determinariam a realidade visível da igreja em meio ao já decadente Império Romano, que fazem surgir o esvaziamento escatológico, ${ }^{1}$ no qual, as esperanças do mundo porvir, que até então eram imediatas e contíguas aos fatos fundantes da fé no Evangelho - morte/ressurreição/ascensão de Cristo, diluem-se cada vez mais nas necessidades prementes das diversas comunidades cristãs de se organizarem e de se sedentarizarem neste mundo, uma vez que a parousia ${ }^{2}$ com seu grito de ordem: Maranatha, ora vem, senhor Jesus, deixa de estar na prioridade da igreja militante e se desloca para uma esperança futura indefinida. Assim, os três primeiros séculos da era cristã nos apresentam uma igreja peregrina, itinerante, buscando, no início, perpetuar e reproduzir o ambiente evangélico, como forma de rememoração nostálgica de seu Senhor, mas que, em meio às lutas doutrinárias com o judaísmo, gnosticismo, marcionismo, montanismo etc., bem como, os embates políticos com as autoridades romanas, especialmente sobre o culto ao imperador, encaram o desafio de se organizar minimamente como corpo social, ainda que não reconhecido legalmente por estar na clandestinidade. É a época das perseguições e martírios, dos apologistas, dos primeiros esboços de teologia, das defesas da fé perante os intelectuais e tribunais civis, da fixação do Cânon, da regula fidei e da sucessão apostólica, como legitimação última da ortodoxia - da correta maneira de crer. O cristianismo era, nesse tempo, a religião dos escravos, cujas exceções vindas da magistratura, da filosofia, do mundo político, apenas confirmavam a regra de sua desinstalação nesse mundo e do desprezo e opróbrio que sofria.

Pertencem a esse momento todo o patrimônio canônico, ainda por demais judaizante e sinagogal do primeiro século, como também o encontro da fé cristã com o helenismo (filosofia, ética, moral, costumes), dos séculos

Tendência interna no cristianismo de se afastar das realidades mais transcendentes assumindo em seu lugar os aspectos imanentes da igreja nesse mundo, como a organização interna, a prática litúrgico-sacramental mais elaborada e no futuro medieval, a cristandade.

2 Na tradição cristã, Parousia = Presença, se refere ao evento central da escatologia, no qual Jesus Cristo volta ao mundo e se apresenta para o Julgamento final. Na literatura grega, o vocábulo indicava a presença ou a visita de um soberano. 
II e III; encontro que fora antecipado pela presença de Paulo, o apóstolo, no Areópago em Atenas. Pode-se perceber a tentativa de descolamento em relação à influência judaica. Aqui se inserem, por exemplo, o modelo pastoral e catequético da Didaqué, ${ }^{3}$ as várias apologias, em particular as de Justino Mártir, as cartas de Inácio de Antioquia, e, sobretudo, o Adversus Haeresis, de Irineu de Lion.

E ademais, a Traditio apostolica de Hipólito de Roma, a radicalização do discurso cristão de Tertuliano, rompendo com a herança filosófica em detrimento da tradição judaica para, em seguida, cair no carismatismo montanista e os importantes avanços nas ciências da exegese e hermenêutica, buscando a recuperação dos fatos históricos ou sua interpretação mais espiritual, respectivamente com os cristãos antioquenos de um lado e os alexandrinos, de outro. Nesse particular, cabe ressaltar a importância do modelo romano de política eclesiástica que, em sua expansão, se impôs na África Proconsular, domínios de Cartago e partes da atual Tunísia e Líbia. Região cristã pródiga em tratados teológicos, documentos eclesiásticos, concílios provinciais e importantes pensadores do cristianismo antigo, ligados a Roma.

O momento $\beta$ (beta) - Começa após o término da "grande perseguição",precisamente com o edito de Milão (313), pelas mãos dos imperadores Constantino e Licinio. Esse ato significa o início de uma nova era para a igreja e marca, por assim dizer, o início do fim do paganismo; pois, gradativamente, Constantino irá, em muitos aspectos, privilegiar a religião cristã. Essa mudança radical ficou conhecida como o "giro constantiniano", uma guinada brusca para o destino do cristianismo.

3 Também chamada de Doutrina dos doze apóstolos. É um documento acerca da vida cotidiana da Igreja primitiva. Provavelmente, foi escrita antes dos anos 90, sendo assim mais antiga que alguns escritos joaninos. Outra hipótese é a de ter sido composta no final do século II, provavelmente na Síria ou Palestina.

4 Que há em comum entre Atenas e Jerusalém? Que acordo pode haver entre a Academia e a Igreja? Entre os hereges e os cristãos? (...) Longe de nós querer fazer um cristianismo estoico, platônico ou dialético! Não queremos abrir discussões ociosas depois de Jesus Cristo, nem temos necessidade de investigação agora que temos o Evangelho. Tendo nossa fé, não desejamos adquirir novas crenças (Da prescrição contra os heréticos, 7, 9-13). Ou, mais ainda, no seu suposto credo quia absurdum, de fato, não pronunciado por Tertuliano, mas deduzido de suas afirmações no seu tratado De carne Christi 5, onde se lê: Credibile quia ineptum est - "crível porque é ilógico".

5 Perseguição sistemática impetrada pelo imperador Diocleciano no ano 303. Considerada a pior de todas, e que ceifou a vida de milhares de cristãos. 
Podemos analisar essa guinada política sob dois ângulos: seus motivos e seus resultados para a igreja. Comecemos pelo último. Os resultados imediatos positivos para a vida da igreja foram espetaculares, senão vejamos, pelo menos em síntese, alguns deles: a) O Estado empreende a construção de importantes igrejas, inclusive já com a forma arquitetônica de basílica; em pouco tempo na cidade de Roma, além da de Latrão, teremos diversas delas. Várias construções também em Nicomédia, Antioquia, Belém e Jerusalém, nessa cidade, o magnífico conjunto do Santo Sepulcro. Em Constantinopla, entre as muitas igrejas construídas, destaca-se a dos Doze Apóstolos, onde Constantino construiu uma sepultura para si; b) A dispensa de impostos e da prestação de serviços públicos para os clérigos; c) A equiparação dos bispos com os altos funcionários do Estado; d) A igreja fica autorizada a receber, por testamento, doações de terras e outros imóveis; e) As sentenças de tribunais eclesiásticos são reconhecidas pelo Estado; e f) Desde 321, o domingo cristão está instituído como dia de descanso.

Danièlou explica que tal política irá acentuar-se, com algumas inflexões apenas, até o fim do reinado. Em princípio, a liberdade de culto é a doutrina oficial; no entanto, a balança está longe de se manter igual entre o paganismo e o cristianismo. Os primeiros símbolos cristãos aparecem nas moedas, que são maravilhosos instrumentos de propaganda, desde 315; as últimas representações pagãs desaparecem em 323.4 Além do mais, em 319 foi proibida a prática da "aruspicina privada", prática pagã de consulta às entranhas de animais para se vaticinar o futuro. Quanto aos motivos para tais mudanças, dois são plausíveis: motivo político e motivo religioso.

Motivo político - uma vez que o número de cristãos crescia a olhos vistos, estando presentes em todos os segmentos da sociedade romana; Constantino, assim, tomava uma medida popular. Isso justificaria também a própria mudança da capital para Constantinopla, como uma mudança de eixo do império para o leste, onde a população cristã era ainda maior que a do Ocidente.

Motivo religioso - A experiência de Constantino na véspera da batalha contra Maxêncio, em 312, na ponte Mílvio, teria sido verdadeira como confirmam Lactâncio e Eusébio. ${ }^{5}$ Essa que posteriormente seria considerada

\footnotetext{
4 J. DANIÈLOU e H. MARROU. Nova história da Igreja: dos primórdios a São Gregório Magno. Petrópolis: Vozes, 1984, p. 248.

5 LACTÂNCIO. De mort. persec. 44; EUSÉBIO DE CESARÉIA. H. E. I, 29-30. In: A. DONINI, História do cristianismo: das origens a Justiniano. Lisboa: Ed. 70, 1988, p. 203-4.
} 
como uma legítima experiência de conversão. Há dúvida sobre isso, já que Constantino recebeu o batismo somente em 336, no seu leito de morte, pelas mãos do bispo Eusébio de Nicomédia.

O momento $\gamma$ (gama) - Refere-se ao aprofundamento teológico da mensagem do Evangelho - intellectus fidei - em um novo ambiente de liberdade e privilégios dados ao cristianismo, tornando-se assim o berço da teologia cristã. Atividade empreendida por parte dos grandes Pais da igreja ${ }^{6}$ e de uma infinidade de escritores, teólogos, pastoralistas etc. Temos, então, um período de crescimento da igreja sem precedentes na história e que produzirá uma literatura teológica, bem como, uma espiritualidade de qualidades incomparáveis. O século IV é, portanto, a época de ouro da história da igreja e que começará, teologicamente, com a crise ariana e com o concilio de Niceia, em 325, com participação direta do imperador Constantino. A política constantiniana de favorecimento ao cristianismo continuará por todo o século IV, não obstante a tentativa efêmera de reimplantação do paganismo por Juliano Apóstata (361-363). Todos os outros imperadores seguintes adotaram o cristianismo. O ponto culminante dessa história é, sem dúvida, o governo de Teodósio (379-395), que realmente oficializa o cristianismo ortodoxo como religião do Estado, ${ }^{7}$ havendo inclusive, nesse período, a perseguição de hereges, bem como, a interdição e em alguns casos, a destruição dos templos pagãos.

Como dissemos, o século IV dá início à época dourada da literatura cristã. Os escritores cristãos têm agora a possibilidade de se concentrarem na construção e desenvolvimento da ciência eclesiástica. Livre da opressão exterior do império, a igreja se dedica a preservar sua doutrina da heresia e a definir seus principais dogmas. Será o início da época dos grandes concílios ecumênicos, e sua característica mais saliente, efeito das disputas cristológicas, é uma intensa atividade teológica.

\footnotetext{
Os Quatro Pais da Igreja Oriental: Basílio de Cesareia, Atanásio de Alexandria, Gregório de Nazianzo e João Crisóstomo. Os Quatro Pais da Igreja Ocidental: Ambrósio de Milão, Jerônimo de Estridão, Agostinho de Hipona, e Gregório Magno.

7 O edito de Teodósio, promulgado em 8 de novembro de 392, "assinala a data do que poderia ser definido como a "morte legal" do paganismo. Todos os sacrifícios e manifestações exteriores do culto, quer em público quer em privado, eram proibidos nos centros urbanos, nos campos e nas casas particulares, sob pena de confiscação dos locais e de outros bens imóveis; os templos deviam ser fechados e deixava-se praticamente o caminho livre para a sua demolição ou para a sua conversão em igrejas cristãs". In: A. DONINI, História do Cristianismo, p. 247.
} 
$O$ momento $\delta$ (delta) - A partir do exemplo inaugurado pelos imperadores Constantino e Teodósio, os poderes espiritual e temporal, da cruz e da espada, convergem para formar uma mesma realidade, engendrando o embrião do que será chamado de Cesaropapismo. ${ }^{8}$ Curiosamente, o caso de Roma chama a atenção, considerando que a mudança da capital do império para o Oriente (Bizâncio) ocasionou um vazio administrativo que gradualmente foi sendo ocupado pelo bispo romano que aglutinou funções espirituais e seculares de liderança. Com isso, o Ocidente ganha um modelo de governabilidade que faz conviver com relativa normalidade o Estado e a igreja, havendo uma comunicação, muitas vezes tensa, porém, contínua, entre o palácio do rei e o palácio episcopal. As relações entre religião e política ganham um capítulo à parte na dinastia carolíngia, ${ }^{9}$ no qual o imperador Carlos Magno, coroado por Leão III, imperador do Sacro Império RomanoGermânico - Imperator Romanorum, no ano 800, prontificou-se a ser o defensor da igreja e fortalecê-la como Estado Pontifício.

Com tais fundamentos, o medievo será invadido, segundo Kantorowicz, "pelas infinitas inter-relações entre a Igreja e o Estado", e, ao final, produzindo:

Híbridos em ambos os campos. Os empréstimos mútuos e os intercâmbios de insígnias, símbolos políticos, prerrogativas e direitos honorários vão se realizando incessantemente entre os dirigentes espirituais e seculares da sociedade cristã. O papa enfeitava sua tiara com uma coroa de ouro, vestia a púrpura imperial e era precedido pelos estandartes imperiais quando cavalgava em solene procissão pelas ruas de Roma... Estes intercâmbios afetaram, na Alta Idade Média, principalmente às pessoas dos governantes, tanto espirituais como seculares, até que finalmente o sacerdotium teve uma aparência imperial e o regnum um toque clerical. ${ }^{10}$

8 Sistema ideológico de governo, no qual o poder secular acumula também o poder sagrado, e o chefe do Estado se torna igualmente o chefe da igreja. Prática política bem desenvolvida no império bizantino, com amplos poderes de intervenção em concílios e sínodos, fazendo cumprir o direito canônico, além da nomeação ou deposição em cargos e ofícios eclesiásticos.

9 Período muito interessante de renascimento cultural das artes, teologia, literatura e política sob o patrocínio do imperador Carlos Magno (742-814), que expandindo o reino franco, por meio de campanhas militares, praticamente definiu tanto a Europa Ocidental quanto a própria Idade Média.

10 E. H. KANTOROWICZ. Los dos cuerpos del rey: um estúdio de teologia politica medieval. Madrid: Alianza Editorial, 1985, p. 188. 
O desfecho desse período deu-se inicialmente a partir da Concordata de Worms (1122), ${ }^{11}$ na qual o papa consegue readquirir sua autonomia em assuntos religiosos e Roma, pouco a pouco, volta a centralizar as atenções da cristandade ocidental, abrindo, por assim dizer, o caminho para a autonomia eclesiástica que se consolida com o Decreto de Graciano (1140-1142) ${ }^{12}$ e, de forma final, com o papado de Inocêncio III (1198-1216) que, conforme explica Barradas, "O novo papa reprimiu com extrema dureza os movimentos maniqueístas das seitas que eclodiram na Provença (França) e dos Valdenses de Lion, de cunho anticlerical, matando vinte mil heréticos". ${ }^{13}$ Após isso, a igreja se tornaria a proprietária de enormes riquezas, grande latifundiária, senhora dos destinos individuais e, obviamente, desencadeou um processo de vaidade e ambição desmedidas com grande concentração de poder e propensão à corrupção, como tráfico de influências, venda de nomeações para cargos eclesiásticos, abusos fiscais e o aumento das despesas com a Cúria romana, fatos que precipitariam uma situação sem precedentes: o Cisma do Ocidente (1378-1417). ${ }^{14}$ Como é sabido, o declínio da igreja veio paralelo à emergência dos nacionalismos e com o seu consequente absolutismo monárquico.

$O$ momento $\varepsilon$ (épsilon) - circunscreve-se à teologia escolástica e à filosofia renascentista dos séculos XIII a XV que, por sua originalidade e sutilezas, muito contribuíram para a discussão sobre religião (teologia) e política.

Se, por um lado, Tomás de Aquino (1225-1274) buscava a síntese entre ratio et fides entre philosophie et theologiae, expandindo tal desejo para o encontro da política com a religião, do Estado com a igreja, era porque, à luz de Aristóteles, entendia que o Estado poderia conduzir bem o ser humano ao priorizar o comportamento virtuoso do governante almejando a paz social que poderia ser alcançada pela unidade do Estado com o concurso da igreja, que cuidaria da dimensão espiritual do destino do Estado, ou seja, sendo a consciência espiritual e moral do Estado; como homem da igreja, não poderia

11 Celebrada entre o papa Calixto II e o imperador Henrique V, ainda que reconhecesse ao imperador na autoridade de investir bispos com autoridade secular para os territórios onde governassem não lhe dava mais a autoridade sagrada, simbolizada no anel e no báculo.

12 Concordia discordantium canonum - Obra culminante do Direito Canônico realizada pelo monge e jurista italiano Graciano que, de forma monumental, conseguiu compilar a quase totalidade das leis eclesiásticas existentes até aquele momento, oriundas das mais diversas fontes, contribuindo, assim, para uma unificação jurídica e consolidação do direito da Igreja Católica.

13 F. da C. BARRADAS. Poder político e religião na Baixa Idade Média cristã. In: http://revistas. unipar.br/akropolis/article/viewFile/1717/1488, p. 36.

14 Época conturbada e de crise na qual o papado foi transferido para Avignon, na França. 
menos que submeter o Estado ao poder espiritual; por outro, Dante Alighieri (1265-1321), em seu De monarchia (1312-1313), defendia a presença de um governante único ao qual todos deveriam obediência, um imperador acima de todos, assegurando um mundo de paz e justiça. Rejeitou de forma enfática a concepção teocrática da igreja e defendeu a autonomia da esfera temporal.

Por sua vez, Marsílio de Pádua (1280-1343), em seu Defensor pacis (1324), propugnava uma separação total entre a igreja e o Estado, desferindo um forte ataque contra as pretensões políticas temporais do papa João XXII, defendendo o poder civil e a soberania popular. De modo diferente de Tomás de Aquino, afirmava que a lei humana, separada da lei divina, que regulava o mundo espiritual, era resultado da vontade dos cidadãos, a única válida neste mundo.

Com isso, fica claro que a recuperação de Aristóteles na escolástica e renascença, seu direcionamento para a ratio e as preocupações voltadas para a condição humana da vida em sociedade, com ênfase na polis, como bem sinalizava o estagirita, chegariam inexoravelmente na autonomia racional como sendo um dom dado pelo próprio Deus ao ser humano. Nesse sentido, porém, por outros caminhos, o filósofo e sacerdote franciscano, Guilherme de Ockham (1295-1349), surge como o pensador mais original e antecipador dos tempos modernos. A partir de ideias de Duns Scotus, um colega de hábito franciscano, adotava o voluntarismo como concepção filosóficojurídica e, em meio à discussão acerca dos universais, "descobre" o particular, o individual, vitalizando sobremaneira o movimento filosófico do nominalismo. Para ele, fora da mente e da linguagem humana, os universais inexistem. Como esclarece Tarnas, "Ockham argumentava que nada existia, a não ser os seres individuais, que somente a experiência concreta poderia servir de base ao conhecimento". ${ }^{15}$

A particularização na ação epistemológica assume o comando na investigação exigida pelos novos tempos que já se avizinhavam, fazendo da experiência a única fonte legítima de conhecimento.

O movimento nominalista e a ênfase no indivíduo tornam consciente o processo de individuação, proporcionando "o reconhecimento do livrearbítrio humano individual e, especialmente, da liberdade de Deus de escolher como criava cada indivíduo; a existência de Deus ou do homem". ${ }^{16}$ Nessa nova concepção filosófica, tais realidades não estariam mais ligadas

\footnotetext{
15 R. Tarnas. A epopéia do pensamento ocidental: para compreender as ideias que moldaram nossa visão de mundo. Rio de Janeiro: Bertrand Brasil, 2008, p. 225.

16 Ibid., p. 226.
} 
ao determinismo de conceitos fixos, num sentido tomista ou aristotélico. Em Ockham, a fé em Deus deve estar separada do conhecimento empíricocientífico, para que ambos se desenvolvam, mantendo-se a integridade de cada qual. Por isso mesmo, sua abordagem será conhecida como via moderna, nada mais correto! Assim, a descoberta do indivíduo torna-se a chave hermenêutica que iria abrir as portas da modernidade, sendo inclusive a conexão filosófica mais importante com o advento da Reforma protestante, conforme infra.

\section{Protestantismo e a modernidade política}

\subsection{Abordagem geral}

O fenômeno religioso protestante, deflagrado com a Reforma, acusa em suas origens, de um significativo e consciente reducionismo quanto ao judaísmo e ao catolicismo, manifesto nas diversas confissões de fé e também nas idiossincrasias internas, normais em qualquer movimento histórico, bem como, certo fideísmo radical. Seu modus operandi e performance social, contudo, em linhas gerais, há que se registrar, foi quase sempre uma negativa competente e corajosa do centralismo dogmático reduzindo e controlando o misterium fidei, esquadrinhando a ordo salutis - diga-se de passagem, uma negativa bem onerosa em médio e longo prazo - pela afirmação tanto da liberdade de consciência como da liberdade religiosa. Posturas que plasmariam indelevelmente sua identidade, criando o que, em seu momento, fora denominado de era protestante, ${ }^{17}$ uma nova alternativa de identidade cristã no Ocidente, quebrando uma hegemonia católica mais que milenar, abrindo com um fórceps interno o monopólio dos bens espirituais.

Por conseguinte, se lhe prestamos a devida atenção, subjazem e lhe sobressaem as raízes religiosas da modernidade no Ocidente, estando a cultura religiosa protestante associada ao advento dessa mesma modernidade. Com muita frequência, destacam-se os fortes laços do protestantismo com esse novo tempo ocidental.

Com efeito, não se pode isolar a Reforma do nascimento do mundo moderno no ocaso da Idade Média. Em corroboração a isso, vale lembrar aqui a declaração do economista e filósofo Alfred North Whitehead que, embora

\footnotetext{
17 Título em língua portuguesa de uma das principais obras do teólogo alemão, radicado nos Estados Unidos, Paul Tillich, The Protestant Era. Esse autor foi de fato o pioneiro no conceito que se estabeleceu a partir dessa obra.
} 
sublinhando que os "reformadores afirmavam que estavam apenas restaurando o que havia sido esquecido", considerava a Reforma e o movimento científico como dois aspectos da reviravolta histórica, constituindo o movimento intelectual dominante da Renascença tardia (2006, 21).

Na mesma linha de raciocínio, vale ainda sublinhar o dito pelo filósofo moral John Rawls, quando destaca a Reforma do século XVI como um dos três processos históricos (com o Estado moderno e a Ciência moderna) que influenciaram para o advento da modernidade, precisamente por sua filosofia moral e política que aqui nos interessa. Segundo ele, a Reforma "fragmentou a unidade religiosa da Idade Média e levou ao pluralismo religioso, com todas as suas consequências para os séculos posteriores. Isso, por sua vez, alimentou pluralismos de outros tipos, que se tornaram uma característica permanente da cultura no final do século XVIII". ${ }^{18}$ Em outras palavras, pode-se perceber uma evidente imbricação histórica entre o protestantismo e a modernidade.

\subsection{Deus e o Homem, Teologia e Política}

O protestantismo se defronta com o Deus absconditus - "totalmente outro", não manipulado e repartido pelo magistério da igreja, nem coisificado e disponibilizado nos sacramentos. O Deus de Lutero e Calvino, em linhas gerais, identifica-se bem com o Deus nominalista de Ockham, concebido como o todo transcendente e absoluto, numinoso - tremendum et fascinosum, diria R. Otto. O moderno na política em Ockham se mostra, entre outras tantas asseverações, na negação da plenitudo potestatis ${ }^{19}$ ao papa e ao imperador, na independência de origem e exercício do poder civil ante o poder eclesiástico etc.

E, nesse espaço, merece destaque o ethos protestante. A gênese do protestantismo esteve marcada, sobretudo, por uma atitude de amor a Deus e às suas obras. Um amor incontido e apaixonado, muitas vezes, inclusive, extremado e inconsequente, mas, fundamentalmente, devotado ao Criador e às suas criaturas. Em linhas gerais, a luz que emana da Reforma estabeleceu duas conquistas: 1) O conceito de Pessoa - sujeito/indivíduo/subjetividade; 2) O princípio de Liberdade - consciência/exame/expressão. Tais conquistas, por sua

8 John Rawls. O Liberalismo político. Brasília: Inst. Teotônio Vilela e Ed. Ática, 2000, p. 30.

19 Sobre as posições políticas de Ockham ver: L. A. DE BONI, De Abelardo a Lutero: estudos sobre a filosofia prática na Idade Média. Porto Alegre: EDIPUCRS, 2003, p. 283-286, em especial a síntese da p. 286. Sobretudo ver: G. de OCKHAM, Brevilóquio sobre o principado tirânico. Petrópolis: Vozes, 1988 e G. de OCKHAM, Obras Políticas II. Porto Alegre: EDIPUCRS/USF, 1999. 
vez, possibilitaram o surgimento de novos paradigmas: a) Redescoberta do texto bíblico - as línguas originais; b) Renovação da teologia - sola gratia/sola fide/ sola scriptura; c) Inserção na sociedade - "ascetismo mundano"; d) Dignificação do trabalho - valorização da atividade mundana; e) Separação entre igreja e Estado; f) Desenvolvimento do parlamentarismo e do espírito democrático; g) Avanço da ciência moderna (XVII) - racionalismo e empirismo. Em síntese, a contribuição protestante poderia ser exposta no seguinte binômio: Luta por uma visão correta do Sagrado-Construção de uma religião cidadã.

Esse carisma inicial condicionaria, de maneira quase plena, sua performance teológica e sua inserção social. Portanto, a alternativa protestante contribuiu inicialmente com a renovação da teologia, recuperando aquelas realidades ontológico-metafísicas que, a partir de então, traduziriam a essência do protestantismo, na forma do trinômio: Fé-Bíblia-Igreja (com a igreja sempre ao final), buscando na arqueologia da fé judaico-cristã as máximas da teologia reformada já tão decantadas: sola fide, sola gratia, sola Scriptura, solus Christus - verdadeiras contribuições espirituais ao patrimônio da identidade protestante no mundo.

A fé é fides ex auditu, não mais a visão da grande igreja medieval, detentora da ordo salutis, mediadora da salvação, estampada na estética da liturgia, 20 “a fé é, em primeira instância, ouvir". No caso da igreja, "em lugar da hierarquia e da encarnação de Cristo que nela se prolonga, aparece a força milagrosa da Bíblia, que tudo produz: a prolongação protestante da encarnação de Deus" (TROELTSCH, 1951, 38), empreende-se aí uma refinada reelaboração da ecclesia invisibilis, a partir, particularmente de Wycliff, no seu tratado De ecclesia e, com isso, se prioriza mais o aspecto do organismo vivo, de atualização no indivíduo do mistério do corpo místico de Cristo e menos o institucional ou, como interpretou magistralmente Barth: ${ }^{21}$

A Igreja não é nem a comunidade, nem o agrupamento visível dos homens que creem em Jesus Cristo, nem o órgão que os representa sob forma monárquica, aristocrática ou democrática. Ela não é uma ideia, nem uma instituição, nem um pacto. Ela é o evento que reúne dois ou três homens em nome de Jesus Cristo, isto é, pelo poder do apelo que lhes dirige e do mandado que lhes confia. A estrutura da Igreja não tem sentido senão pela relação com este evento: a congregação viva.

\footnotetext{
20 Sobre isso ver a interessantíssima reflexão do pensador protestante francês Jacques Ellul, especialmente em A palavra humilhada. São Paulo: Paulinas, 1984.

21 In: Laurent Gagnebin, O protestantismo. Lisboa: Instituto Piaget, 1998, p. 42.
} 
Nesse particular, Tillich faz coro com Barth ao declarar que "Religião e Igreja não são garantias para os protestantes. Nunca poderão ter esse status" (TILLICH, 1992, p. 215). Tratar da Theologia - sacra doctrina ou sacra scientia, a partir das aproximações e diferenças desses dois "ícones" da teologia, seria estimulante e "desafiador"; contudo, nesse momento, o nosso intuito é "menos nobre", desvia-se da teologia clássica; desejamos tão-somente tentar recuperar a contribuição sociopolítica do fenômeno protestante. A respeito da importância da Reforma na dinâmica da sociedade ocidental, Talcott Parsons ${ }^{22}$ salienta que a Reforma foi um movimento ainda mais radical de mudança cultural e influiu profundamente nas relações entre os sistemas culturais e a sociedade.

\subsection{Desdobramentos Políticos: Paradoxo e Ambivalência}

Filosoficamente, parece que isso supõe a existência de uma ontologia metafísica que inspiraria o modelo político de auctoritas em Thomas Hobbes (1588-1679) e que se estende, sabemos bem, politicamente ao soberano representante de Deus na terra, sem, contudo, significar uma intervenção eclesiástica na dimensão temporal - os tempos são outros e os poderes estão separados, especialmente desde Nicolau Maquiavel (1469-1527) no início do século XVI. Evidente que, em termos religiosos, o protestantismo, propondo a separação entre igreja e Estado, alinha-se naturalmente ao lado do nominalismo e do voluntarismo franciscano ockhamista que, se antepondo à ideia da síntese tomista, como já dito, reafirmará de modo incisivo a modernidade nascente, a separação dos conhecimentos - divino e humano agora autônomos e livres para seguirem o curso de sua vocação. Nunca será demais lembrar que essa conquista se tornaria fundamental para o nascimento da ciência moderna no século XVII.

Entretanto, esse mesmo protestantismo está erigido na ambivalência e no paradoxo: pois ressalta sobremaneira a soberania absoluta de Deus em detrimento do libero arbitrio humano, porém, simultaneamente, destaca, como quase nenhum outro sistema religioso, a individualidade bumana, com o princípio da liberdade. Dessa forma, o segmento religioso protestante inglês será um espaço amplo o bastante para abrigar, de um lado, o absolutismo hobbesiano e, de outro, o liberalismo de John Locke (1632-1704), ${ }^{23}$ por exemplo, e entre eles

22 In: O sistema das sociedades modernas. São Paulo: Pioneira, 1974, p. 63.

23 A relação entre o conceito de indivíduo, processo de individuação, nominalismo, protestantismo e a filosofia empirista de Locke é hoje mais que evidente. Para o aprofundamento dessas questões, ver: C. G. QUIRINO e M. T. SADEK (orgs.), O pensamento político clássico. São Paulo: Martins Fontes, 2003. Em especial o capítulo 8, Raymond Polin, "Indivíduo e comunidade”, p. 157-196. 
um sem-número de movimentos religiosos com interessantes posicionamentos politicossociais, compondo o rico espectro cultural inglês daquele momento. Com efeito, a versão inglesa do protestantismo - o anglicanismo - buscou ser uma espécie de via média, ou terceira via ${ }^{24}$ - aquele ponto de equilíbrio equidistante entre o catolicismo - associado ao obscurantismo medieval, contudo, possuidor de uma herança inesgotável e insubstituível: a teologia patrística-monástica-escolástica, riquíssima em sua pluralidade cultural, bem como, uma liturgia milenar, principal instrumento de formatação da identidade judaico-cristã ocidental, verdadeiros tesouros da fé cristã. E o protestantismo clássico, como um movimento de vanguarda dos novos tempos, protagonista central na recuperação do texto bíblico e de suas máximas norteadoras: sola gratia... - além das doutrinas do sacerdócio universal dos santos e da liberdade de consciência, exame e expressão, como afirmado supra.

Esse "caminho do meio", esse espaço forjado politicamente entre catolicismo e protestantismo, enfim, essa alternativa, tornou-se cada vez mais larga e ampla, possibilitando que a dinâmica das circunstâncias históricas cuidasse de elaborar um mix de ingredientes, quer dizer, uma mistura de elementos, como se fora um grande caldeirão, contendo ideias filosóficas, políticas e principalmente religiosas. É bem verdade que a representatividade católica tornou-se cada vez menor, no patamar das decisões governamentais, desde a mudança religiosa efetuada por Henrique VIII (1491-1547) e, especialmente, após a "conspiração da pólvora" em 1605, ${ }^{25}$ mas ainda assim, por conta de uma forte presença na espiritualidade popular, mesmo o catolicismo tinha o seu espaço na Inglaterra do século XVII.

\section{Da liberdade religiosa: panorama jurídico}

A liberdade religiosa é uma espécie da liberdade de pensamento. Como a nossa Constituição de 1988 é bem garantista, o legislador quis elencar também dentro do capítulo de Direitos e garantias fundamentais a proteção à liberdade religiosa.

24 "Terceira via" ou "via média" são expressões vinculadas ao anglicanismo, que buscava um ponto mediano entre Roma e Genebra, também a partir das reflexões de Richard Hooker (1554-1600), em sua principal obra: Of the laws of ecclesiastical polity (1594), que propunha a leitura das Escrituras considerando tanto a razão humana quanto a tradição da igreja, levando-se em conta as circunstâncias culturais, políticas, econômicas etc.

25 Tentativa malsucedida de católicos ingleses, por não usufruírem de direitos iguais aos protestantes, de assassinar o rei Jaime I (1566-1625), em sua visita anual ao Parlamento, com sua família e ainda toda a aristocracia protestante, reunidos no dia 5 de novembro. 
A Constituição Federal, em seu artigo 5, inciso VI, preceitua que é inviolável a liberdade de consciência e de crença, sendo assegurado o livre exercício dos cultos religiosos e garantida, na forma da lei, a proteção aos locais de culto e suas liturgias.

Apesar de a Constituição de 1988 ser bem mais ampla e garantista em relação ao direito de liberdade religiosa, outras constituições já abordavam o tema, como a Constituição de 1891, a primeira a tratar o Estado brasileiro como sendo um país laico.

Diz o texto constitucional de 1891:

Artigo 72 - A Constituição assegura a brasileiros e a estrangeiros residentes no País a inviolabilidade dos direitos concernentes à liberdade, à segurança individual e à propriedade, nos termos seguintes:

$\ 3^{\circ}$. - Todos os indivíduos e confissões religiosas podem exercer pública e livremente o seu culto, associando-se para esse fim e adquirindo bens, observadas as disposições do direito comum.

Desse modo já se percebe, ainda que de forma mitigada, uma proteção à liberdade de culto, garantindo a cada cidadão o seu direito de manifestar livremente a sua crença e sua fé. A professora Maria Lucia Karan, em uma de suas célebres obras, aponta que [...] livre, o indivíduo, naturalmente, deve poder pensar e acreditar naquilo que quiser. É esse o campo da liberdade de pensamento, de consciência e de crença. É um campo que diz respeito somente ao indivíduo, não podendo sofrer qualquer interferência do Estado. É um campo essencialmente ligado à própria ideia existente de democracia, pois sem um pensamento livre não existe a possibilidade de escolha que está na base dessa ideia.

Destarte, é de fundamental importância assegurar aos indivíduos a liberdade de crença e de expressão por meio de suas religiões. Contudo, no Estado Brasileiro, ainda existe muito preconceito no que tange ao culto religioso, bem como fenômenos de intolerância religiosa, que cada vez mais só alimentam discursos de ódio.

Visando uma forma de abrandar o ódio e a intolerância religiosa, o legislador constituinte de 1988 pensou em uma forma de conscientizar os alunos acerca da tolerância e liberdade religiosa. In verbis, o artigo 210, parágrafo primeiro da Constituição brasileira, prevê o ensino religioso como matéria facultativa nas cadeiras do ensino fundamental. Assim, o legislador 
pensou em alternativa educadora de abordar temas como liberdade religiosa e tolerância às diferentes religiões existentes no Brasil.

Outra forma de garantir a liberdade religiosa foi a concessão de imunidade tributária aos templos religiosos no Brasil, preceituada no artigo 150, inciso I, da Constituição Federal, alcançando de maneira eficaz o direito de liberdade religiosa pleno.

Por sua vez, não poderia deixar, de uma forma estanque, a ideia de relacionar a religião com um tema já amplamente discutido dentro das academias e dos tribunais superiores do Brasil - o diálogo com a terceira dimensão dos Direitos Humanos.

Desse modo, percebe-se que o Brasil muito avançou na defesa das liberdades e garantias religiosas, porém, ainda precisamos avançar muito mais, principalmente no tocante ao respeito das religiões alheias.

Nesse sentido, a Declaração dos Direitos Humanos das Organizações das Nações Unidas é uníssona em afirmar, acerca do aspecto garantista da liberdade religiosa, em seu artigo XVIII da convenção que toda pessoa tem o direito à liberdade de pensamento, consciência e religião; esse direito inclui a liberdade de mudar de religião ou crença e a liberdade de manifestar essa religião ou crença, pelo ensino, pela prática, pelo culto e pela observância, isolada ou coletivamente, em público ou em particular.

Atualmente, o único trabalho pragmático, que existe como uma forma de políticas públicas governamentais, é o trabalho que a Secretaria Nacional dos Direitos Humanos realiza. Com a institucionalização do Programa Nacional dos Direitos Humanos, houve a possibilidade de um diálogo crítico entre os movimentos religiosos e a sociedade, no escopo de preservar a liberdade religiosa e afastar o discurso do ódio dentro das discussões religiosas.

\section{Considerações finais}

Faz-se necessário recordar que, uma vez rompida a unidade religiosa do Ocidente, o protestantismo permitiu o florescimento, no cenário culturalreligioso, da ideia da tolerância (trataremos disso mais adiante), dando assim, crédito ao pluralismo de interpretações, ou seja, a possibilidade concreta de se considerar o "outro divergente" - a alteridade, também como fonte de iluminação na busca da verdade. Ao insistir demasiadamente na liberdade, ao afirmar desse modo os direitos humanos individuais diante das instituições 
- que não mais eram infalíveis - o protestantismo favoreceu a chegada da democracia, embora não se possa falar aqui de um nexo causal.

Poderíamos, então, sem o receio de exageros, definir o protestantismo, originalmente, como uma importante força cultural libertária na construção da cidadania ocidental, incluindo-se aí a política. Entretanto, sua dinamicidade interna revelou aspectos paradoxais inconciliáveis. Aqui, qualifica-se tal performance de "luzes" e "sombras". No caso brasileiro, esse fenômeno ficou bem evidente, com a negação, no interior do próprio protestantismo, do “princípio protestante”, na renúncia à sua vocação primeira: a Liberdade, bem como, os seus corolários. Era latente em relação à cultura brasileira como um todo, tornou-se evidente a partir de meados da década de 60, acompanhando e, em muitos momentos, apoiando o Golpe Militar acontecido no Brasil e, na verdade, em praticamente toda a América Latina.

Essa opção que já vale a pena aqui, à guisa de conclusão, registrar as mudanças sofridas pelo protestantismo brasileiro, na denúncia de alguém que viveu precisamente aquele momento:

O sentido da Reforma Protestante está em que ela redescobriu a liberdade. Lutero chegou a dar a um de seus tratados mais lindos o título de: 'A Liberdade do Homem Cristão'... Estou convencido, entretanto, que uma estranha metamorfose se processou. A comunidade de liberdade se esqueceu, traiu e se rebelou contra ela... que a comunidade de fé já emigrou. Nenhuma estrutura legal e de poder pode contê-la, ou domesticá-la. ${ }^{26}$

Com as reflexões mencionadas, tenta-se a construção de um pensamento teológico relevante para a sociedade brasileira, que simultaneamente devolva ao protestantismo o seu ethos, parte integrante de sua identidade; enfim, a elaboração de um tipo de Teologia Pública em prol da cidadania; uma guinada de paradigma com vistas a uma real participação social do protestantismo na "cidade", pari passu a uma consideração efetiva da tolerância como princípio axial de convivência; a partir da oportunidade ímpar do pluralismo e do desafio do diálogo, como valores centrais do Evangelho. Dessa maneira, entendemos, haveria possibilidades mínimas para uma ação eclesial relevante na sociedade onde o protestantismo poderia ser, de fato, um agente cultural cooperante, somando-se a outros na promoção de justiça e solidariedade.

26 Trecho da carta de Rubem Alves ao seu presbitério, apud João Dias de Araújo, Inquisição sem fogueiras: vinte anos de história da Igreja Presbiteriana do Brasil. Rio de Janeiro: ISER, 1985, p. 99. Há uma nova edição deste livro: Inquisição sem fogueiras: São Paulo: Fonte Editorial, 2010. 
E, ainda, contribuir com a força crítica, que a religião nos irradia, a construir um mundo mais justo e igualitário, de maneira que os discursos e tensões não ultrapassem a barreira da discussão racional e científica.

\section{Referências}

ARAÚJO. J. D. de. Inquisição sem fogueiras: vinte anos de história da Igreja Presbiteriana do Brasil. Rio de Janeiro: ISER, 1985.

BARRADAS, F da C. Poder político e religião na Baixa Idade Média cristã. In: http:// revistas.unipar.br/akropolis/article/viewFile/1717/1488.

CAVALCANTE, R. Espiritualidade cristã na história: das origens até santo Agostinho. São Paulo: Paulinas, 2007.

A cidade e o gueto: introdução a uma teologia pública protestante e o desafio do neofundamentalismo evangélico no Brasil. São Paulo: Fonte Editorial, 2010.

DANIÈLOU, J. e MARROU, H. Nova história da Igreja: dos primórdios a São Gregório Magno. Petrópolis: Vozes, 1984.

DE BONI, L. A. De Abelardo a Lutero: estudos sobre a filosofia prática na Idade Média. Porto Alegre: EDIPUCRS, 2003.

DONINI, A. História do cristianismo: das origens a Justiniano. Lisboa: Ed. 70, 1988.

GAGNEBIN, L. O protestantismo. Lisboa: Instituto Piaget, 1998.

KANTOROWICZ, E. H. Los dos cuerpos del rey: um estúdio de teología política medieval. Madrid: Alianza Editorial, 1985.

KARAM, Maria Lúcia. Proibições, crenças e liberdade: o direito à vida, a eutanásia e o aborto. Rio de Janeiro: Lumen Juris, 2009.

OCKHAM, G. Brevilóquio sobre o principado tirânico. Petrópolis: Vozes, 1988.

. Obras Políticas II. Porto Alegre: EDIPUCRS/USF, 1999.

QUIRINO, C. G. e SADEK, M. T. (orgs.). O pensamento político clássico. São Paulo: Martins Fontes, 2003.

RAWLS, John. O Liberalismo político. Brasília: Inst. Teotônio Vilela e Ed. Ática, 2000.

TARNAS, R. A epopéia do pensamento ocidental: para compreender as ideias que moldaram nossa visão de mundo. Rio de Janeiro: Bertrand Brasil, 2008.

TOSI, R. Dicionário de sentenças latinas e gregas. São Paulo: Martins Fontes, 2000.

TROELTSCH, E. El protestantismo y el mundo moderno. México: Fondo de Cultura Económica, 1951.

Submetido em: 5-4-2017

Aceito em: 7-8-2018 